\title{
Hepatitis B: knowledge, awareness, vaccination and serological status of vocational school of health services students at a state university in Turkey
}

\section{Demet Hançer Aydemir}

Suleyman Demirel University, Isparta Vocational School of Health Services, Medical Services and Techniques Department, Isparta/Turkey

\begin{abstract}
Aim. In this study, the aim is to evaluate the knowledge level about hepatitis B (HBV) of the students receiving education in vocational school of health services, who are a risky group for HBV infection, and to examine their awareness and immune status.

Material and methods. The data of this research was collected by a questionnaire prepared by the researcher. The sample in the study consisted of $537(81.4 \%)$ students. The data were evaluated using the SPSS 16.0 package program. Frequency, percentage, Pearson chi-square and Fisher's exact test was used in the analyzation of the data.

Outcomes and conclusions. It was determined that the students who participated in the research did not show sufficient sensitivity to get vaccinated against HBV and to know their serological status. It was also identified that they had a lack of knowledge and/or did not have clear information about the modes of transmission of HBV, its treatment, and that HBV may cause cirrhosis. The results of this research will guide students in the trainings to be given in order to raise their awareness on this subject and to ensure that they are immunized before they start working and have practical training in the field of healthcare.
\end{abstract}

Keywords: hepatitis B, students, knowledge, awareness, vaccination, serological status

\section{INTRODUCTION}

Hepatitis B (HBV) infection is one of the most common infections in the world and in our country. While the disease may be life-threatening in its acute phase, it may lead to serious complications such as chronic hepatitis, cirrhosis and hepatocellular carcinoma if it is not fully cured [1]. In epidemiological terms of HBV infection, Turkey is among moderaterisk countries and seroprevalence of HBV varies from region to region [2]. There are modes of transmission of HBV infection such as parenteral, perinatal, horizontal and sexual contact [3]. The most common modes of transmission of HBV infection among healthcare personnel are; percutaneous contact, such as needle used for patients accidentally sticking into the hand, injury with cutting tools contaminated with infected blood, splashing of infected blood or body fluids on mucous membranes [4]. Protection from this pathogen transmitted with blood and body fluids is possible by preventing contact, vaccination and post-contact prophylaxis [5].

Students studying in the field of health services are under serious risk in terms of HBV infection both during their education and in their professional lives. These people, who are in close contact with the patients, can get the disease from the patients as well as infect patients themselves. They also play a significant role in informing the public about hepatitis. Therefore, they must have sufficient and accurate information about the disease in the first place. 


\section{AIM}

This research was conducted to evaluate the knowledge of the students studying in the field of health services about HBV infection, and to determine their awareness and immune status.

\section{MATERIAL AND METHODS}

It is a descriptive research. The research population consisted of 660 students studying in the Vocational School of Health Services at a state university, in Turkey, in the 2018-2019 academic year, and the research sample consisted of 537 students $(81.4 \%)$ who agreed to participate in the study and could be reached.

Written permission was obtained from the Vocational School of Health Services Directorate for the study and the students who agreed to participate in the study were asked to give verbal consent to the researcher. However, only volunteer students were included in the study and no student was forced to participate in the survey. Before beginning to collect research data, it was stated that the information obtained would be kept confidential by explaining the purpose of the research. Additionally, after the survey was completed, the questions of the students were answered and information about the subject was given. No student refused to participate in the research.

The data were obtained by applying the questionnaire prepared by the researcher in May 2019 in line with the principles defined for healthcare workers in the relevant literature and for protection from infections transmitted by blood and body fluids [6,7]. The questionnaire form was applied 20 minutes before the end of the lesson, with the permission of the relevant instructor. The questions were focused on the demographic characteristics, HBV infection history, vaccination and serological status, current knowledge and awareness of HBV.

The data obtained were evaluated by a SPSS (16.0) package program. In the statistical analyses, (f) represents frequency, (\%) percentage. Chi-square $\left(X^{2}\right)$, and Fisher's exact Chi-square test procedures were applied in order to test the differences and $\mathrm{p}<0.05$ was accepted significant.

\section{RESULTS}

\section{Demographic characteristics}

As can be seen in Table 1, 34.3\% of the students participating in the survey were studying at First and
Emergency Aid Program, 29.8\% of them were studying at Medical Laboratory Techniques Program, $11.5 \%$ of them were studying at Elderly Care Program, $11.0 \%$ of them were studying at Medical Imaging Techniques Program, 5.0\% of them were studying at Physiotherapy Program, 5.6\% of them were studying at Anesthesia Program and $2.8 \%$ of them were receiving education on Oral and Dental Health Programs. More than half of the students $(58.8 \%)$ were in the first grade and $41.2 \%$ of them were in the second grade. Among the students, $34.6 \%$ were male, $65.4 \%$ were female and $32.6 \%$ of these students were in the $17-18$ age range, $54.6 \%$ of them were in the $19-20$ age range and $12.8 \%$ of them were 21 and over. While $48.2 \%$ of the students participating in the survey were graduated from vocational health high schools, $51.8 \%$ graduated from other high schools. While $7.6 \%$ of the surveyed students were working in health institutions, $92.4 \%$ were not working. It was found that $26.8 \%$ of the 41 students working in the health institution worked for less than 6 months, $12.2 \%$ of them worked for $6-12$ months, $39.0 \%$ of them worked for $1-3$ years and $22.0 \%$ of them worked for more than 3 years.

TABLE 1. The demographic characteristics of the students participating in the research $(n=537)$.

\begin{tabular}{|c|c|c|c|}
\hline $\begin{array}{l}\text { Students } \\
\text { characteristics }\end{array}$ & Variables & $\mathbf{n}$ & $\%$ \\
\hline \multirow{7}{*}{$\begin{array}{l}\text { Enrolled } \\
\text { program }\end{array}$} & First and Emergency Aid & 184 & 34.3 \\
\hline & $\begin{array}{l}\text { Medical Laboratory } \\
\text { Techniques }\end{array}$ & 160 & 29.8 \\
\hline & Elderly Care & 62 & 11.5 \\
\hline & $\begin{array}{l}\text { Medical Imaging } \\
\text { Techniques }\end{array}$ & 59 & 11.0 \\
\hline & Physiotherapy & 27 & 5.0 \\
\hline & Anesthesia & 30 & 5.6 \\
\hline & Oral and Dental Health & 15 & 2.8 \\
\hline \multirow{2}{*}{ Gender } & Female & 351 & 65.4 \\
\hline & Male & 186 & 34.6 \\
\hline \multirow{3}{*}{ Age range } & $17-18$ & 175 & 32.6 \\
\hline & $19-20$ & 293 & 54.6 \\
\hline & 21 and over & 69 & 12.8 \\
\hline \multirow{2}{*}{ Grade } & 1st Grade & 316 & 58.8 \\
\hline & 2nd Grade & 221 & 41.2 \\
\hline \multirow{2}{*}{$\begin{array}{l}\text { Type of } \\
\text { high school } \\
\text { graduated }\end{array}$} & $\begin{array}{l}\text { Vocational Health High } \\
\text { Schools }\end{array}$ & 259 & 48.2 \\
\hline & Others & 278 & 51.8 \\
\hline \multirow{2}{*}{$\begin{array}{l}\text { Working status } \\
\text { in health } \\
\text { institutions }\end{array}$} & Yes & 41 & 7.6 \\
\hline & No & 496 & 92.4 \\
\hline \multirow{4}{*}{$\begin{array}{l}\text { Duration of } \\
\text { work }\end{array}$} & $<6$ months & 11 & 26.8 \\
\hline & 6-12 months & 5 & 12.2 \\
\hline & 1-3 years & 16 & 39.0 \\
\hline & $>3$ years & 9 & 22.0 \\
\hline
\end{tabular}




\section{HBV infection history}

It was determined that $1.3 \%$ of the students were HBV patients, $0.4 \%$ were HBV carriers and continued receiving medical checkups, 9.9\% did not know whether they had HBV or not, and 5.2\% had an HBV history in their family (Table 2). It was found that $10.7 \%$ of the students with HBV in their family were diagnosed with HBV, 3.6\% were carriers, 82.1\% were not diagnosed with $\mathrm{HBV}$ and $3.6 \%$ did not know whether they were infected with HBV $(p<0.05)$. It was determined that $35.7 \%$ of the students with $\mathrm{HBV}$ in their family had an immune response and $64.3 \%$ did not know whether they were immune or not $(\mathrm{p}<0.05)$. When family members who had HBV disease were questioned, it was found that $42.8 \%$ had this disease in their mother and/or father, $28.6 \%$ in their siblings, and $28.6 \%$ in other family members such as aunts and uncles (Table 2).

TABLE 2. The history of HBV infection among the students participating in the research

\begin{tabular}{|c|c|c|c|}
\hline & Variables & $\mathrm{n}$ & $\%$ \\
\hline \multirow{4}{*}{$\begin{array}{l}\text { Do you have HBV } \\
\text { or have you been } \\
\text { diagnosed with such } \\
\text { a condition? }\end{array}$} & Yes & 7 & 1.3 \\
\hline & No & 475 & 88.4 \\
\hline & $\begin{array}{l}\text { I'm the carrier, I'm } \\
\text { in control }\end{array}$ & 2 & 0.4 \\
\hline & I have no idea & 53 & 9.9 \\
\hline \multirow{2}{*}{$\begin{array}{l}\text { Do you have HBV in } \\
\text { your family? }\end{array}$} & Yes & 28 & 5.2 \\
\hline & $\begin{array}{l}\text { No } \\
\text { I have no idea }\end{array}$ & $\begin{array}{c}448 \\
61 \\
\end{array}$ & $\begin{array}{l}83.4 \\
11.4\end{array}$ \\
\hline \multirow{3}{*}{$\begin{array}{l}\text { If yes, which family } \\
\text { members have HBV? }\end{array}$} & Mother, father & 12 & 42.8 \\
\hline & Sibling & 8 & 28.6 \\
\hline & Other (aunt, uncle) & 8 & 28.6 \\
\hline
\end{tabular}

\section{HBV vaccination status and distribution of serological status}

It was found that $32.6 \%$ of the students had their HBV serology checked, $50.8 \%$ did not have it checked, and $16.6 \%$ did not remember whether they had such a test. It was determined that $41 \%$ of the students had the HBV vaccine, $40.8 \%$ did not and $18.2 \%$ did not remember whether or not they were vaccinated (Table 3 ). It was confirmed that there was no statistically significant relationship between the gender of the students participating in the study and their vaccination status $(\chi 2=3.198, p=0.202)$. When the students' reasons for not having HBV vaccine were questioned, it was found that $33.8 \%$ of them did not know that there was HBV vaccine in preventing the disease, $26.9 \%$ neglected to be vaccinated, $13.7 \%$ were unaware of the importance and severity of the disease, $3.2 \%$ feared vaccination, $1.9 \%$ forgot to be vaccinated and $20.5 \%$ were not vaccinated for other reasons. It was determined that $51.4 \%$ of those who had HBV vaccine received all doses of the vaccine, $10.5 \%$ did not receive all the doses, $2.3 \%$ are still vaccinated, and $35.8 \%$ did not remember whether they received all doses. However, it was confirmed that only $31.4 \%$ of the students had antibody titer measurements performed after vaccination to determine whether there was immunity or not, $36.8 \%$ did not and $31.8 \%$ did not remember having it performed (Table 3). It was found that there is a statistically significant relationship between HBV diagnosis and HBV surface antibody (anti-HBs) test status ( $\mathrm{p}<$ 0.05 ). When the students were asked whether they had immune responses to HBV, it was found that $25 \%$ had an immune response, $0.2 \%$ did not, and $74.8 \%$ did not know whether there was an immune response (Table 3). It was determined that there is a statistically significant relationship between the HBV immunity of the students and their gender $(\mathrm{p}<0.05)$. It was determined that there is a statistically significant relationship between HBV vaccination and immunity against HBV. It was determined that $40.9 \%$ of those who had $\mathrm{HBV}$ vaccine had an immune response against hepatitis B, and $59.1 \%$ of them did not know whether they were immune or not. $20.1 \%$ of those who did not have HBV vaccine before stated that they had an immune response against HBV.

\section{Current knowledge and awareness of students on HBV infection}

$27.4 \%$ of the students who participated in the survey stated that, they participated in a training program on HBV infection, $72.6 \%$ of them stated that they did not receive any training. It was determined that there is a statistically significant relationship between the students' working in a health institution and their education about HBV infection $(\chi 2=9.099$, $\mathrm{p}=0.000$ ). It was found that there is no statistically significant relationship between the education level of the students and their education status about HBV $(\chi 2=1.633, p=0.201)$. It has been determined that $99.5 \%$ of 390 people who have not received any training on HBV infection want to participate in a training program. It was confirmed that $86.2 \%$ of the students had knowledge about HBV disease or heard about it before. It was determined that there is a statistically significant relationship between having 
TABLE 3. HBV vaccination status and distribution of serological status of the students

\begin{tabular}{|c|c|c|c|}
\hline & Variables & n & $\%$ \\
\hline \multirow{3}{*}{$\begin{array}{l}\text { Have you had HBV } \\
\text { serology checked? }\end{array}$} & Yes & 175 & 32.6 \\
\hline & No & 273 & 50.8 \\
\hline & I have no idea & 89 & 16.6 \\
\hline \multirow{2}{*}{$\begin{array}{l}\text { Have you had an HBV } \\
\text { vaccine before? }\end{array}$} & Yes & 220 & 41.0 \\
\hline & $\begin{array}{l}\text { No } \\
\text { I have no idea }\end{array}$ & $\begin{array}{c}219 \\
98\end{array}$ & $\begin{array}{l}40.8 \\
18.2\end{array}$ \\
\hline \multirow[b]{3}{*}{$\begin{array}{l}\text { If your answer is no; } \\
\text { Why did you not get an } \\
\text { HBV vaccine before? }\end{array}$} & Neglecting & 59 & 26.9 \\
\hline & Forgetting & 4 & 1.9 \\
\hline & $\begin{array}{l}\text { Not knowing } \\
\text { the severity / } \\
\text { importance of the } \\
\text { disease } \\
\text { Not knowing that } \\
\text { the disease has a } \\
\text { vaccine } \\
\text { Fear of vaccination } \\
\text { Other reasons } \\
\end{array}$ & $\begin{array}{c}30 \\
74 \\
7 \\
45\end{array}$ & $\begin{array}{c}13.7 \\
33.8 \\
3.2 \\
20.5\end{array}$ \\
\hline $\begin{array}{l}\text { If your answer is yes; } \\
\text { Have you received all } \\
\text { doses of the vaccine? }\end{array}$ & $\begin{array}{l}\text { Yes } \\
\text { No } \\
\text { Continues } \\
\text { I do not remember }\end{array}$ & $\begin{array}{c}113 \\
23 \\
5 \\
79\end{array}$ & $\begin{array}{c}51.4 \\
10.5 \\
2.3 \\
35.8\end{array}$ \\
\hline $\begin{array}{l}\text { If your answer is yes; } \\
\text { Have you had antibody } \\
\text { titer measurement } \\
\text { made to determine } \\
\text { whether immunity } \\
\text { has occurred after } \\
\text { vaccination? }\end{array}$ & $\begin{array}{l}\text { Yes } \\
\text { No } \\
\text { I have no idea }\end{array}$ & $\begin{array}{l}69 \\
81 \\
70\end{array}$ & $\begin{array}{l}31.4 \\
36.8 \\
31.8\end{array}$ \\
\hline $\begin{array}{l}\text { Do you have an } \\
\text { immune response to } \\
\text { HBV? }\end{array}$ & $\begin{array}{l}\text { Yes } \\
\text { No } \\
\text { I have no idea }\end{array}$ & $\begin{array}{c}134 \\
1 \\
402\end{array}$ & $\begin{array}{c}25.0 \\
0.2 \\
74.8\end{array}$ \\
\hline
\end{tabular}

HBV patients in the family of students and their having heard of this disease before $(\chi 2=33.473$, $\mathrm{p}=0.001)$. When the sources of information of the students who received information about HBV were questioned, they stated that they obtained information about $\mathrm{HBV}$ infection $48 \%$ via school or teachers, $27.6 \%$ healthcare workers, $7.4 \%$ internet, $6 \%$ books or brochures, $5.4 \%$ friends, $2.8 \%$ family, $2.6 \%$ radio or television and $0.2 \%$ via the printed media. Although $78.8 \%$ of the students knew that there is a vaccine against HBV disease, $21.2 \%$ of them did not (Table 4 ).

It was found that only $23.8 \%$ of the students answered correctly by saying 3 doses to the question of how many doses of HBV vaccine should be given, and $76.2 \%$ did not know how many doses of HBV vaccine should be given (Table 4).

$67.3 \%$ of the students said they did not consider themselves at risk for HBV, $32 \%$ said they were at risk, and $0.7 \%$ said they did not know if they were at risk (Table 4). It was found that there was no statistically significant relationship between having HBV patients in the family and students seeing themselves in the risk group for HBV $(p=0.158)$.
It was found that $70.2 \%$ of the students have knowledge that HBV can also be transmitted from a healthy-looking person. It was determined that $57.2 \%$ of the students knew that a mother with HBV can transmit the virus to her child during childbirth. It was determined that $75.4 \%$ of the students knew that HBV can be transmitted by needles or other sharp objects. It was found that $70.6 \%$ of the students knew that HBV can be transmitted by splashing blood and saliva to the nose, eyes or mouth. It was determined that only $24.8 \%$ of the students knew that the disease would not be transmitted by sharing the kitchen utensils of a person with HBV. It was found that $45.1 \%$ of the students knew that the disease would not be transmitted by eating the meal cooked by a person with HBV (Table 4). It was determined that there is a statistically significant association between having HBV patients in the family and knowing the modes of transmission of HBV $(\mathrm{p}<0.05)$.

It was confirmed that $27.6 \%$ of the students knew that HBV can cause cirrhosis. In addition, it was confirmed that $10.6 \%$ of the students stated that HBV would not cause cirrhosis, and $61.8 \%$ answered that they did not know (Table 4).

It was determined that only $17.9 \%$ of the students responded correctly by answering there is no definitive treatment for $\mathrm{HBV}$ disease, $47.7 \%$ stated that there is a treatment and $34.4 \%$ answered that they did not know (Table 4). A statistically significant relationship was found between having HBV patients in the family and knowing the definitive treatment of HBV disease $(\chi 2=27.350, p=0.000)$.

\section{DISCUSSIONS}

Hepatitis B virus is basically transmitted parenterally, by percutaneous and mucosal contact with infected blood and fluids, by transmission from the carrier mother to the infant (vertical transmission), and by sexual intercourse with the infected person [8]. In addition to these transmission modes, HBV transmission also occurs in the same dwelling and in close living conditions (horizontal transmission). Common living conditions are thought to cause transmission, especially in family members of HBV carriers, where other modes of transmission are not involved [9]. Since the virus can survive outside the human body for more than seven days, infected toothbrushes and razors can also be a source of transmission [10]. It was confirmed that $5.2 \%$ of the students had an HBV 
TABLE 4. Current knowledge and awareness of students on HBV infection

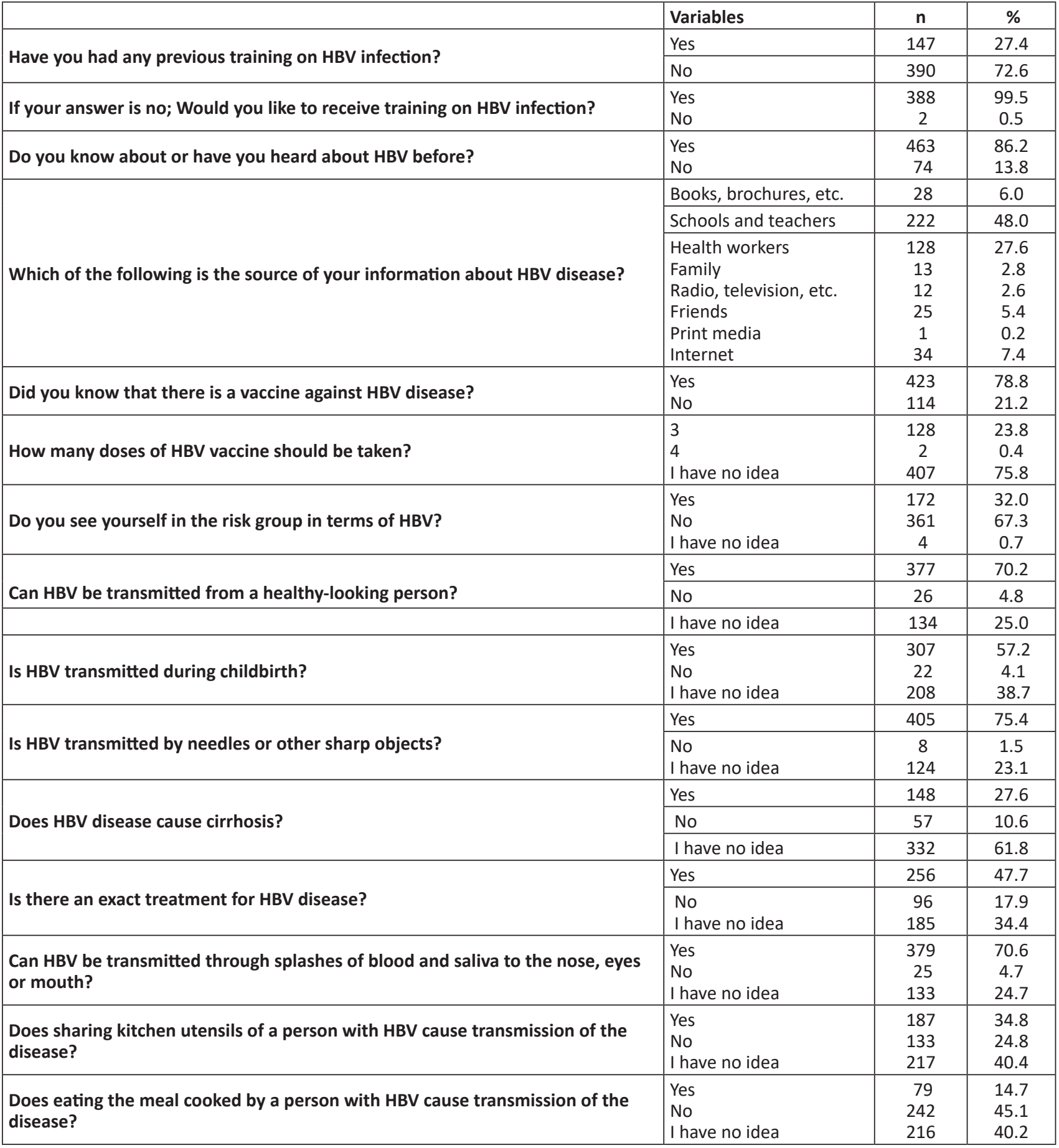

history in their family. It was determined that $10.7 \%$ of the students with HBV in their family were diagnosed with HBV, $3.6 \%$ were carriers, $82.1 \%$ were not diagnosed with HBV and $3.6 \%$ did not know if they were infected with HBV $(p<0.05)$. It can be said that domestic transmission was low in the group participating in the study. It was found that $35.7 \%$ of the students with HBV in their family had an immune response, while $64.3 \%$ did not know whether they were immune $(\mathrm{p}<0.05)$. When family members who had HBV were questioned, it was found that $42.8 \%$ had this disease in their mother and/or father, $28.6 \%$ in their siblings, and $28.6 \%$ in other family members such as aunts and uncles. In another study, the presence of hepatitis B in family members was questioned and it was detected primarily in mothers (44.1\%) among family members. Again, in the same study, this rate was reported as $13.7 \%$ in siblings [11].

$72.6 \%$ of the students who participated in the study pointed out that they had not received any training on $\mathrm{HBV}$ infection previously and $99.5 \%$ of 
the students who had not received any training stated that they would like to be trained on HBV infection. In the study conducted by Çetin et al. $73.3 \%$ of the participants in the questionnaire said that would like to receive training on the subject [12]. It was determined that there is no statistically significant correlation between the education level of the students and whether or not they had received a training on HBV $(\chi 2=1.633, p=0.201)$. On the other hand, $70.6 \%$ of the first grade students and $75.6 \%$ of the second grade students remarked that they had not received any training on HBV infection. While $48 \%$ of the students who were trained on HBV infection stated that they had obtained information on hepatitis at school and $2.6 \%$ said they had received through the radio and television broadcasts. In a similar study conducted among university students, $54.8 \%$ of the participants had not received any information or training on HBV infection, and when the sources of information of the participants receiving training were questioned, it was reported that $21.6 \%$ of the students had received it at school, and $10.2 \%$ through the radio and television [13]. What is remarkable here is that the rate of those who acquired information on hepatitis by way of the radio and television is very low. This rate may be said to be even lower among average citizens. Therefore, it would not be wrong to conclude that the media must give more coverage to this issue and students and the general public must be given more information.

It is a well-known fact that HBV infection risk is ten times higher for healthcare workers compared to the control groups [14]. However, in this study, $67.3 \%$ of the students stated that they did not consider themselves to be in the risk group for HBV, $32 \%$ stated that they were in the risk group and $0.7 \%$ said that they did not know whether they were in the risk group. One of the measures which may be taken to reduce the risk is to check the immune status of healthcare workers against $\mathrm{HBV}$ and immunize those susceptible to infection by inoculation. However, it was seen that the students who took part in the study did not know about the importance of vaccination for prevention against HBV. Because only $41 \%$ of the students had been vaccinated against HBV; $40.8 \%$ of them had not been vaccinated in spite of all the risks. It was found out that $51.4 \%$ of those who had been vaccinated had received all doses of the vaccine, while $35.8 \%$ did not remember whether they had been given all doses or not. It was determined that there is a statistically significant correlation between the immunity rate and gender $(\mathrm{p}<0.05)$. It was found out that $23.9 \%$ of those with an immune response to HBV were men and $76.1 \%$ were women. However, in another study conducted, it was reported that there is no association between anti-HBs seropositivity and gender [15]. It was determined that there is a statistically significant correlation between receiving $\mathrm{HBV}$ vaccination and immunity against $\mathrm{HBV}$ $(p<0.05)$. It was determined that $40.9 \%$ of those who had had HBV vaccine had an immune response against hepatitis $\mathrm{B}$, and $59.1 \%$ did not know whether they were immune to HBV or not. $20.1 \%$ of those who had not had HBV vaccine before stated that they had an immune response against HBV. However, $68.6 \%$ of those who had had their vaccines did not know about their anti-HBs status. Vaccinated healthcare staff must be tested in order to check the formation of anti-HBs antibodies 1 to 2 months after the completion of three doses of vaccine. There is no need for booster doses or monitoring of antibody titers once an anti-HBs level of $10 \mathrm{mIU} / \mathrm{ml}$ is achieved after three doses of vaccine are administered [16]. In this study, it was found out that only $31.4 \%$ of the students had antibody titer measurements performed after vaccination to determine whether there was immunity or not, and only $25 \%$ knew that they had an immune response. Similarly, in the study conducted by Tomruk et al., it was reported that $28.4 \%$ of those who had had a HBV vaccine had the vaccine checked serologically [17]. Checking whether an antibody response has occurred or not is very important to ensure that people who do not have an antibody response behave more cautiously. School boards and/or infection committees should make it compulsory for students studying healthcare to receive all doses before they start their applied training and practice; in addition, anti-HBs titers must be measured in order to determine whether or not an immune response has developed. In a study conducted by Uzun et al. in order to evaluate the immunization status, awareness and attitude as regards HBV of 222 research assistants actively working in a faculty of medicine the HBV vaccination rate was found to be $68.4 \%$, and it was reported that the research assistants were not sensitive enough about being vaccinated against HBV and were indifferent to finding out whether they were immune or not [18]. In other studies in Turkey, anti-HBs positivity among healthcare workers were reported as $87.5 \%$ [19] and 92.4\% [20]. 
However, in this study, it was seen that the rate of those who declared that they had an immune response against $\mathrm{HBV}$ was quite low (25\%), and most of the students who participated in the study did not show awareness for vaccination against HBV and were not anxious to find out about their immune response status. When the answers to the question whether they have had HBV vaccines by students studying healthcare at another vocational school of higher education were evaluated, it was reported that $39.60 \%$ of the participants answered "yes", 36.50\% answered "no", and $24 \%$ answered "I don't know", which are similar to the results obtained in our study [21]. Especially for healthcare workers and students, who comprise higher risk groups, carrying out screening tests for HBV and awareness of seropositivity as well as immunization for prevention are all of importance. In this respect, it is of great importance that healthcare professionals and students are screened for seropositivity intermittently and those who are seronegative for HBV be included in the vaccination program and the employees be trained on this. Especially, antiHBs titers of those who stated that they had already been vaccinated should be checked at an appropriate time after vaccination.

When the reasons for not having HBV vaccine were questioned, it was determined that $33.8 \%$ of the participants did not know that there was a HBV vaccine for the prevention of the disease, $26.9 \%$ neglected it, $13.7 \%$ were not aware of the importance and seriousness of the disease, $3.2 \%$ were afraid to be vaccinated, $1.9 \%$ forgot to be vaccinated and $20.5 \%$ of them were not vaccinated owing to other reasons. However, it was seen that these results were not compatible with those obtained in similar studies conducted in our country, and the reasons for not being vaccinated declared by most of the students were reported to be negligence and lack of opportunity $[17,22]$. In a study on university students conducted by Şahin et al., it was reported that $35.6 \%$ of the students had not received an HBV vaccine. It was reported that the reasons for students not being vaccinated were negligence $(58.3 \%)$, not being aware of the seriousness of HBV infection (20.2\%), not knowing that there was a vaccine for the prevention of the disease (13.9\%), and fear of vaccination (7.6\%) [13].

The known and most common form of transmission for viral hepatitis is coming into contact with infected blood and blood products. The risk is proportional to the degree and duration of one's direct contact with blood and body fluids. Therefore, students who run the risk of being exposed to blood and other body fluids are under constant risk of viral hepatitis infections during their clinical practice owing to their insufficient medical experience [23]. When infected saliva gets into one's mucosa, although it may be very low, it is accepted that there is a possibility of being infected [4]. In this study, it was observed that $70.2 \%$ of the students were aware of the possibility of HBV transmission from a seemingly healthy person. It was determined that $70.6 \%$ of them knew that HBV can be transmitted by blood and saliva splashes in the nose, eyes or mouth, and $75.4 \%$ by needle stick or cutting oneself with other sharp objects. On the other hand, it was found that the percentage of the students who declared that the disease would not be transmitted by sharing the food and beverage containers used by a person with HBV and eating food cooked by a person with HBV was lower in our study group (24\% and $45.1 \%$ respectively). The rate of those who do not know that a mother with HBV can transmit the virus to her baby at birth was found to be $42.8 \%$. In another study, $75.7 \%$ of the students said that HBV was transmitted by birth, $94.1 \%$ by blood and $28.6 \%$ by personal belongings [24]. Similarly, in this study, too, it was seen that they had insufficient knowledge, especially about contamination with personal belongings. In a study on protection from $\mathrm{HBV}$ and transmission routes the disease conducted by Göktalay et al. on 392 students studying at a medical faculty, a healthcare school and a vocational school of healthcare services, it was seen that students' awareness of HBV was not sufficient [25]. Both in this study and in other studies, it was found that the most known transmission way of HBV among students was through blood. Fewer students knew about other ways of transmission [26]. Training should be encouraged on other modes of transmission of HBV other than blood.

HBV infection is one of the important health concerns as it may lead to fulminant hepatitis in the acute phase or acute exacerbation periods, chronic hepatitis, liver cirrhosis and liver cancer [27]. In this study, the percentage of those who know that HBV may cause cirrhosis was found to be $27.6 \%$. Similar results were found in studies conducted on higher school of healthcare and high school students $[25,28]$. In the study by Çetin et al., the question whether or not it might cause cirrhosis was answered $100 \%$ correctly [12]. 
HBV infection, the importance of which is increasing in the world and Turkey, still does not have an effective treatment and the current treatments are rather costly. Therefore, preventing HBV infection must be given primacy. The most effective way of preventing $\mathrm{HBV}$ is to gain active immunity against it through vaccination [29]. It was observed that only $17.9 \%$ of the students gave the correct answer that there is no definitive treatment for HBV disease, $47.7 \%$ stated that it had a treatment and $34.4 \%$ answered "I don't know". In the study conducted by Savaşer et al., it was observed that the percentage of those who gave correct answers to this question (11.6\%) was similar [28].

This study had several limitations. The research was done on Vocational School of Health Services students of a state university in Turkey. So, these findings cannot be generalised. Students who agreed to participate were included in the study. The most important limitation of the study is that most of the data on immunity status are on students' statements.

\section{CONCLUSIONS}

As a result, in this study, the subjects that the students knew the least as regards HBV were that it would not be transmitted by sharing food and beverage containers used by HBV positive people, there was no definitive treatment and the disease could cause cirrhosis. In order to raise the awareness of students on HBV, it is essential that HBV be given a wide coverage, modes of transmission and preventive measures be taught in addition to the curriculum; and after graduation, in-service training programs and refresher training be offered, publications on hepatitis be raised, more coverage on the issue be given in the visual media, and all students be actively immunized before they come into contact with patients, which will help to protect the health of healthcare workers as well as public health. To that end, it may be suggested that screening and vaccination become a routine at schools where healthcare professionals are trained, and keeping a record to ensure that all students carry out the necessary checks before clinical practice.

\section{Acknowledgement}

To all the students who participated in the present study.

Conflict of interest: none declared Financial support: none declared

\section{REFERENCES}

1. Demir I, Kaya S, Demirci M, Cicioğlu-Arıdoğan B. Investigation of seropositivity of hepatitis B virus in healthcare workers in Isparta, Türkiye. Turkish Journal of Infection. 2006;20(3):183-187.

2. Çakaloğlu Y, Ökten A, Yalçın S. Seroepidemiology of hepatitis B virus in Turkey. Turk J Gastroenterol. 1990;1(1):49-53.

3. Şahin Y, Aydın D. Seroprevalence of hepatitis B under age six. Fırat Medical Journal. 2005;10(4):169-172.

4. Komatsu H, Inui A, Fujisawa T. The role of body fluids in the horizontal transmission of hepatitis $B$ virus via household/close contact. EMJ. 2016;1(1):68-75.

5. Sridhar MR, Boopathi S, Lodha R et al. Standart precautions and post exposure prophylaxis for preventing infections. Indian J Paediatr. 2004;71(7):617-626.

6. Bolyard EA, Tablan OC, Williams WW et al. Guideline for infection control in healthcare personnel, 1998. Hospital infection control practices advisory committee. Infect Control Hosp Epidemiol. 1998;19(6):407-463.

7. Inci A. Knowledge level of healthcare workers about hepatits $B$ in a state hospital. Clin Anal Med. 2015;6(1):18-20.

8. Bilgiç A, Özacar T. Hepatitis B virus. In: Topçu AW, Söyletir G, Doğanay M. (eds.) Infectious diseases and microbiology. 2nd ed. İstanbul: Nobel Medical Bookstore; 2008:1350-1370.

9. Chen WN, Oon CJ, Koh S. Horizontal transmission of a hepatitis B virus surface antigen mutant. J Clin Microbiol. 2000;38(2):938-939.

10. Schillie S, Vellozzi C, Reingold A et al. Prevention of hepatitis B virus infection in the United States: Recommendations of the advisory committee on immunization practices. MMWR Recomm Rep. 2018;67(1):1-31.
11. Baş B. Prevalence and interfamily transmission pathways of hepatitis B virus. The Turkish Journal of Academic Gastroenterology. 2017; 16(1):12-17.

12. Çetin M, Temiz M, Aslan A et al. Determination of the knowledge levels on hepatitis B virus of residents at Mustafa Kemal University Hospital. Viral Hepat J. 2007;12(3):121-127.

13. Şahin N, Akın S, Durna Z. Knowledge and attitudes toward hepatitis B of university students. HEAD. 2010;7(2):36-43.

14. Akın L. Hepatitis B, Control of diseases transmitted by blood and blood products. In: Güler Ç, Akın L. (eds.) The basics of public health. 2nd ed. Ankara: Printing House of Hacettepe University Hospital, 2006:940-943.

15. Acikgoz A, Cimrin D, Kizildag S et al. Hepatitis A, B and C seropositivity among first-year healthcare students in western Turkey: a seroprevalence study. BMC Infect Dis. 2020;20:529.

16. Baxter D. Specific immunization issues in the occupational health setting. Occup Med (Lond). 2007;57(8):557-563.

17. Tomruk CÖ, Özkurt Z, Gürsoy $\mathrm{H}$ et al. Evaluation of status, knowledge levels and attitude of students in Yeditepe University Faculty of Dentistry on hepatit B infection. Cumhuriyet Dent J. 2011;14(2):78-91.

18. Uzun $E$, Akçam $F$, Zengin $E$ et al. Evaluation of the hepatitis $B$ infection status, knowledge and behaviours of the research assistants of SDU School of Medicine. Medical Journal of Süleyman Demirel University. 2008;15(1):22-27.

19. Kutlu R, Terlemez A, Demirbaş N et al. Evaluation of hepatitis A and hepatitis B seroprevalence in Dental Faculty students and staff. TJFMPC. 2020;14(2):246-251. 
20. Sönmez M, Akben M. Status of immunization and seroprevalance hepatitis $B$, hepatitis $C$ in nursing students. Journal of Health Services and Education. 2020;4(1):19-23.

21. Sarar E, Kadakal F, Çelik Ö et al. The level of knowledge and awareness levels of 1 . st year students studying, in vocational school about infectious diseases transmitting to health workers and their own immune status. Sakarya Med J. 2020;10(1):1-10.

22. Çelik Y, Akduman D, Kıran S. Evaluation of healthcare workers' and students' knowledge levels about infections transmitted by blood and body fluids, infection control measures, exposure frequencies and serological and hepatitis B vaccination status. Turkiye Klinikleri J Med Sci. 2010;30(4):1246-1255.

23. Kaygusuz TÖ. The examination of support healthcare personal knowledge about hepatitis. Firat University Medical Journal of Health Sciences. 2006;20(6):441-444.

24. Gülerman HF, Güven B, Katırcıoğlu M et al. The hepatitis B knowledge level of medicine students at Kırıkkale University. The Journal of Kırıkkale University, Faculty of Medicine. 2017. 19(2):66-72.
25. Göktalay T, Özyurt BC. Seroprevalence of hepatitis B and the hepatitis B knowledge level of the university and vocational school students studying at health professional training at Celal Bayar University. Viral Hepat J. 2010;15(1):13-21.

26. Slonim AB, Roberto AJ, Downing CR et al. Adolescents' knowledge, beliefs, and behaviors regarding hepatitis $\mathrm{B}$ : Insights and implications for programs targeting vaccine-preventable diseases. J Adolesc Health. 2005;36(3):178-186.

27. Çivi S, Marakoğlu K, Bitirge B. Epidemiology and cost-analysis of viral hepatitis cases. Turkish Journal of Family Practice. 2006;10(2):64-70.

28. Savaşer $\mathrm{S}$, Balcı $\mathrm{S}$, Ceylan $\mathrm{N}$ et al. Awareness about the hepatitis $\mathrm{B}$ and prevention of hepatitis $\mathrm{B}$ among high school students. FNJN. 2011;19(1):1-8.

29. Gençkil E, Savaş R, Şahin T et al. Evaluation of the efficiency of training programs given to second stage primary school students on hepatitis-B. Journal of Hacettepe University Faculty of Nursing. 2010;17:30-40. 